4. Про затвердження Положення про трудовий арбітраж : Наказ Національної служби посередництва і примирення від 18.11.2008 p. № 135. URL: https://cutt.ly/KtathLx (Дата звернення: 10.10.2019) C. $76-80$.

5. Кузніченко О.В. Трудові конфлікти: шляхи їх вирішення. Право і Безпека. 2002. № 2.

УДК 349.2

DOI https://doi.org/10.32844/2618-1258.2019.6.15

ЛЮБИМОВ О.к.

\title{
КОМПЛЕКС ОСНОВНИХ ПРАВ ПРОФЕСІЙНОГО ПУБЛІЧНОГО СЛУЖБОВЦЯ В УКРАЇНІ
}

Стаття присвячена 3'ясуванню комплексу основних прав професійного публічного службовця в Україні. Автор критично аналізує чинне законодавство в частині, що регулює права державних службовців та службовців органів місцевого самоврядування, а також досліджує наукову літературу, в якій вже розглядалась проблематика відповідного елементу правового статусу цих публічних службовців. Особлива увага приділяється ретельній систематизації прав професійних публічних службовців у межах відповідних груп і підгруп, а також з'ясуванню достатності наявних прав професійних публічних службовців й їх змінюваності в процесі триваючої реформи законодавства про публічну службу. Наголошується на тому, що нормативне закріплення прав службовців в органах місцевого самоврядування $є$ дещо вужчим за обсяг прав держслужбовців. При цьому, на відміну від підходу, використаного в Законі України «Про державну службу», Закон України «Про службу в органах місцевого самоврядування» не містить застереження про те, що перелік основних прав відповідних професійних публічних службовців не $\epsilon$ вичерпним. Крім того, звертається увага на те, що в процесі реформи «Перезавантаження влади» відбувається звуження прав публічних службовців, що суперечить європейському праву та рекомендаціям Ради Європи, а також концепції гідної праці публічних службовців в Україні. 3'ясовано, що модернізація системи публічного адміністрування а тій чи іншій мірі позначається на правосуб'єктності професійних публічних службовців, що підтверджує, зокрема, розпочатий у вересні 2019 року етап реформи публічної служби, що отримав назву «Перезавантаження влади» й критикується українськими вченими. Зроблено висновок, що в узагальненому вигляді службово-трудові права публічних службовців складаються з таких груп прав: 1) права публічного службовця як людини і громадянина у сфері праці головним чином; 2) права публічного службовця, пов'язані з належним перебігом службово-трудових обов'язків; 3 ) права публічного службовця, що мають забезпечити належний рівень соціальної безпеки держслужбовців.

Ключові слова: державні службовці, права, правовий статус, професійні публічні службовиі, трудові права.

The article focuses on clarifying the complex of fundamental rights of a professional public servant in Ukraine. The author critically analyzes the current legislation in the part regulating the rights of civil servants and local government officials, as well as examines the scientific literature, which has already examined the problems of the corresponding element of these public servants' legal status. Particular attention is paid to the careful systematization of the rights of professional public servants within the relevant groups

(С ЛЮБИМОВ О.К. - кандидат юридичних наук, помічник судді (Вищий господарський суд 
and subgroups, as well as to the sufficiency of the existing rights of professional public servants and their changes within the ongoing reform of public service legislation. It is emphasized that the normative consolidation of the rights of officials in local governments is somewhat narrower for the scope of rights of public servants. At the same time, in contrast to the approach used in the Law of Ukraine "On Civil Service", the Law of Ukraine "On Service in Local Government" does not contain a reservation that the list of fundamental rights of the relevant professional public servants is not exhaustive. In addition, attention is drawn to the fact that in the process of the "Reloading of power" ongoing reform, the rights of public servants are being narrowed, contrary to European law and the recommendations of the Council of Europe, as well as the concept of decent work for public servants in Ukraine. It is revealed that the modernization of the public administration system in one way or another affects the legal personality of professional public servants, which confirms, in particular, the phase of public service reform, dubbed "Power restart", launched in September 2019, and criticized by Ukrainian scientists. It is concluded that, in a generalized form, public service labor rights consist of the following groups of rights: 1) the rights of a public servant as a person and citizen in the sphere of work, mainly; 2) the rights of a public servant in connection with the proper course of duty; 3 ) the rights of a public servant to ensure the proper level of social security for civil servants. rights.

Key words: civil servants, labor rights, legal status, professional public servants,

Вступ. Від об'єму та характеру прав і обов'язків професійних публічних службовців залежить ефективність їхньої професійної діяльності, а отже, оптимальне функціонування державного органу, органу місцевого самоврядування, держави (саме як демократичної, соціальної та правової держави) [1, с. 24-29]. 3 огляду на це для публічних службовців як для спеціальної групи працівників, ефективність трудової діяльності котрих вимагає наявності особливих трудових прав і обов'язків, законодавчо закріплюються відповідні службово-трудові права, здійснення в практичній дійсності яких припускає як досягнення публічним службовцем мети своєї особливої трудової діяльності, так і досягнення органом публічної служби мети свого створення та існування.

Таким чином, права професійних публічних службовців мають особливе значення для них як для працівників (сприяють належному здійсненню трудових обов'язків в умовах соціальної безпеки) і представників публічної адміністрації (сприяють належному здійсненню публічного адміністрування), а тому можуть змінюватись у своєму об'ємі та характері у процесі поточних реформ законодавства та модернізації системи публічної служби в Україні. Як відомо, «права працівників визначають цінності суспільства та орієнтують на економічне й соціальне процвітання економіки» [2, с. 172]. Безумовно, права публічних службовців у цьому контексті не є виключенням, а тому реформа трудового законодавства та законодавства про публічну службу, що триває, в комплексі з модернізацією публічної адміністрації в Україні не може відбуватись шляхом звуження трудових прав публічних службовців, нормативного окреслення цих прав в умовах дисбалансу прав і обов'язків працівників. Вказане має також додаткове значення з огляду на те, що звуження трудових прав публічних службовців, невиправдана дискримінація цих службовців у правах порівняно з іншими працівниками суперечить:

1) вибудовуванню України як соціальної і правової держави. Правова держава «забезпечує рівність трудових прав усіх громадян незалежно від їх походження, соціального й майнового стану, расової та національної належності, статі, мови, політичних поглядів, релігійних переконань, роду й характеру занять, місця проживання та інших обставин» [3, с. 126]. Це безпосереднім чином стосується й публічних службовців, які можуть бути обмежені в своїх трудових правах (порівняно з іншими працівниками) лише з огляду на потребу забезпечення загального блага, яке досягається в процесі трудової діяльності в системі публічної служби;

2) процесу європеїзації вітчизняного законодавства, що триває, адже такі дії безпосередньо не відповідають праву ЄС, зокрема, Директиві Ради СС «Щодо рамкових угод із визначеним строком роботи укладених ETUC, UNICE та CEEP» від 28 червня 1999 року № 1999/70/ЄC, а також Рекомендаціям Комітету Міністрів Ради Європи державам-членам «Щодо статусу публічних службовців в Європі» від 24 лютого 2000 року № R (2000)6 (далі - Рекомендації Комітету Міністрів РЄ від 24 лютого 2000 року № R (2000)6). 
Постановка завдання. Трудові права працівників, враховуючи також й публічних службовців, вже були предметом багатьох досліджень українських вчених, зокрема, Л.П. Амелічевої, О.Б. Андрєєва, О.І. Бедного, Ю.П. Битяка, І.А. Грицяка, М.О. Іллічіва, М.І. Іншина, Т.П. Мороза, О.В. Петришина. Результати наукових досліджень цих та інших науковців стануть нормативним фундаментом для узагальнення й актуалізації наукової думки про права професійних публічних службовців, що раніше не досліджувались у контексті публічної служби загалом та з урахуванням поточного реформування публічної адміністрації і модернізації правового статусу публічних службовців. Окреслена мета досягатиметься шляхом: 1) аналізу чинного законодавства в частині, що регулює права професійних публічних службовців, а також наукової літератури, в якій вже розглядалась проблематика відповідного елементу правового статусу цих публічних службовців; 2) ретельної систематизації прав і обов'язків професійних публічних службовців у межах відповідних груп і підгруп прав і обов'язків; 3) з'ясування достатності наявних прав і обов'язків професійних публічних службовців й їх змінюваності у процесі реформи законодавства про публічну службу, що триває; 4) з'ясування особливостей оцінювання належної реалізації прав і обов'язків професійних публічних службовців.

Результати дослідження. Професійні публічні службовці в Україні $\epsilon$ працівниками, котрі здійснюють трудову діяльність, представляючи державу чи місцеве самоврядування, а тому вони є суб' єктами трудового права, котрі мають спільні та спеціальні для держслужбовців і службовців органів місцевого самоврядування службово-трудові права.

У ч. 1 ст. 7 Закону України «Про державну службу» міститься перелік основних прав держслужбовців, який не є вичерпним, що випливає з ч. 2 зазначеної статті Закону (ці службовці «також реалізують інші права, визначені у положеннях про структурні підрозділи державних органів та посадових інструкціях, затверджених керівниками державної служби в цих органах»). 3 огляду на вказану норму та підходи вчених до класифікації цих прав $[4$, с. 81$]$, можемо дійти висновку, що службово-трудові права держслужбовців складаються з таких груп прав цього виду професійних публічних службовців України:

1) права державного службовця як людини і громадянина у сфері праці, головним чином: a) право на повагу до своєї особистості, честі та гідності, справедливе і шанобливе ставлення з боку керівників, колег та інших осіб; б) право на участь у професійних спілках із метою захисту своїх прав та інтересів; в) право на участь у діяльності об'єднань громадян, крім політичних партій у випадках, передбачених Законом України «Про державну службу»;

2) права державного службовця, пов'язані з належним перебігом службово-трудових обов'язків, а саме: а) право на чітке визначення посадових обов'язків; б) право на безперешкодне ознайомлення з документами про проходження ним держслужби, у тому числі висновками щодо результатів оцінювання його службової діяльності; в) право на отримання від державних органів, підприємств, установ та організацій, органів місцевого самоврядування необхідної інформації з питань, що належать до його повноважень, у випадках, встановлених законом; г) право на професійне навчання, зокрема державним коштом, відповідно до потреб державного органу; г) право на просування по службі з урахуванням професійної компетентності та сумлінного виконання своїх посадових обов'язків;

3) права державного службовця, що мають забезпечити належний рівень соціальної безпеки держслужбовців, а саме: а) право на належні для роботи умови служби та їх матеріально-технічне забезпечення; б) право на оплату праці залежно від обійманої посади, результатів службової діяльності, стажу державної служби, рангу та умов контракту про проходження державної служби (у разі укладення); в) право на відпустки, соціальне та пенсійне забезпечення відповідно до закону; г) право на оскарження в установленому законом порядку рішень про накладення дисциплінарного стягнення, звільнення з посади державної служби, а також висновку, що містить негативну оцінку за результатами оцінювання його службової діяльності; г) право на захист від незаконного переслідування з боку державних органів та їх посадових осіб у разі повідомлення про факти порушення вимог Законом України «Про державну службу»; д) право на проведення службового розслідування за його вимогою з метою зняття безпідставних, на його думку, звинувачень або підозри.

Що ж стосується основних прав службовців в органах місцевого самоврядування, то 3 цього приводу варто зауважити, що в Законі України «Про службу в органах місцевого самоврядування» закріплено чіткий перелік основних прав відповідних службовців. Спершу звернемо увагу на те, що у ст. 5 цього законодавчого акта визначається право на службу в органах місцевого самоврядування, яке «мають громадяни України незалежно від раси, кольору шкіри, полі- 
тичних, релігійних та інших переконань, статі, етнічного та соціального походження, майнового стану, терміну проживання на відповідній території». У цьому контексті на посаду можуть бути призначені особи, котрі мають відповідну освіту і професійну підготовку, володіють державною мовою та регіональними мовами в обсягах, достатніх для виконання службових обов'язків відповідно до вимог ст. 11 Закону України «Про засади державної мовної політики». Вказане право має важливе значення, адже залишається за особою навіть тоді, коли вона його реалізувала (воно унеможливлює несправедливе припинення реалізації цього права).

У ст. 9 Закону України «Про службу в органах місцевого самоврядування» до основних прав посадових осіб місцевого самоврядування законодавцем зараховано сукупність прав, які можна поділити на такі групи службово-трудових прав службовців в органах місиевого самоврядування:

1) права службовия в органах місиевого самоврядування як людини і громадянина у сфері $n p a u i$, головним чином право на повагу особистої гідності, справедливе і шанобливе ставлення до себе з боку керівників, співробітників і громадян;

2) права службовия в органах місиевого самоврядування, пов'язані з належним перебігом службово-трудових обов'язків, а саме: а) право на просування по службі відповідно до професійної освіти, результатів роботи та атестації; б) право на безпечні та необхідні для високопродуктивної роботи умови праці; в) право отримувати в порядку, встановленому законодавством, від відповідних органів державної влади, органів влади АР Крим та органів місцевого самоврядування, підприємств, установ, організацій, незалежно від їх підпорядкування та форм власності, об'єднань громадян, окремих осіб матеріали та інформацію, необхідні для виконання своїх службових обов'язків;

3) права службовия в органах місиевого самоврядування, щзо мають забезпечити належний рівень соиіальної безпеки цього службовия, а саме: а) право на оплату праці залежно від посади, яку вона займає, рангу, який ій присвоєно, якості, досвіду та стажу роботи; б) право на соціальний і правовий захист; в) право вимагати проведення службового розслідування з метою спростування безпідставних, на ії думку, звинувачень або підозри щодо неї; г) право на отримання в порядку і в межах, встановлених законом, інформації щодо матеріалів своєї особової справи та ознайомлюватися 3 іншими документами, що стосуються проходження нею служби в органах місцевого самоврядування, отримувати від керівників органу місцевого самоврядування відповідні пояснення та давати особисті пояснення; г) право захищати свої законні права та інтереси в органах державної влади, органах влади АР Крим, органах місцевого самоврядування та в судовому порядку.

Доходимо висновку, що нормативне закріплення прав службовців в органах місцевого самоврядування є дещо вужчим за обсяг прав держслужбовців. При цьому, на відміну від підходу, використаного в Законі України «Про державну службу», у Законі України «Про службу в органах місцевого самоврядування» не міститься застереження про те, що перелік основних прав відповідних професійних публічних службовців не є вичерпним.

Наукове осмислення прав професійних публічних службовців як елементу їх правового статусу дає змогу розуміти цих службовців як категорії осіб, які обіймають посади в публічних органах та виконують різноманітні важливі функції держави (чи місцевого самоврядування), представляють органи публічної служби в різноманітних взаємовідносинах у рамках системи публічної адміністрації й поза нею (з парламентом та з іншими органами, склад яких формується 3 обраних осіб у процесі голосування на місцевих і загальнонаціональних виборах; із суспільством; із громадянином і людиною, підприємствами, установами, організаціями; міжнародними органами, міжнародними спільнотами тощо). Саме тому до осіб, яких, безумовно, варто вважати представниками влади і держави (місцевого самоврядування), висувається низка службово-трудових вимог щодо їхньої професійності, компетенції, поведінки, культури спілкування, етики тощо, що формують об’єм їхньої правосуб'єктності, який у практичній дійсності виявляється в правах і обов'язках публічного службовця, основні з яких закріплені на рівні спеціальних законів України. Отже, модернізація системи публічного адміністрування у тій чи іншій мірі позначається на правосуб'єктності професійних публічних службовців, що підтверджує, зокрема, розпочатий у вересні 2019 року етап реформи публічної служби, що отримав назву «Перезавантаження влади» й критикується українськими вченими $[5$, с. 39-40; 6, с. $53,125-126,330]$ як такий, що значно погіршує можливий потенціал концепції гідної праці на публічній службі, а тому знижує рівень забезпечення соціальної безпеки публічних службовців, зокрема, шляхом звуження можливостей вияву службово-трудових прав цих працівників. Варто констатувати, що 
«Перезавантаження влади» спричинило створення таких нормативних умов здійснення службово-трудової діяльності державних службовців, в яких права цих службовців як громадян і працівників були надзвичайно звужені, що $є$ зворотним кроком у процесі європеїзації професійної публічної служби України. Це суперечить праву СС (зокрема, Директиві Ради СС від 28 червня 1999 року № 1999/70/СС) і рекомендаціям Ради Європи (наприклад, Рекомендації Комітету Міністрів РС від 24 лютого 2000 року № R (2000)6). Зокрема, модифікація особливостей звільнення зі служби держслужбовця, а також правил зміни істотних умов державної служби (відображає право на доступ до державної служби, право на гідну працю тощо) суперечать п. 16 додатку до Рекомендацій Комітету Міністрів РЄ від 24 лютого 2000 року № R (2000)6, що вказує на неприпустимість звуження правових гарантій публічних службовців, котрі спрямовані на захист публічних службовців від зловживань влади.

Висновки. Аналіз ч. 1 ст. 7 Закону України «Про державну службу» та ст. 9 Закону України «Про службу в органах місцевого самоврядування» дає змогу дійти висновку, що нормативне закріплення прав службовців в органах місцевого самоврядування $\epsilon$ дещо вужчим за обсяг службово-трудових прав держслужбовців. При цьому, на відміну від підходу, використаного в Законі України «Про державну службу», Закон України «Про службу в органах місцевого самоврядування» не містить застереження про те, що перелік основних прав відповідних професійних публічних службовців не $є$ вичерпним.

В узагальненому вигляді службово-трудові права публічних складаються з таких груп прав:

1) права публічного службовця як людини і громадянина у сфері праці (право на повагу до своєї особистості, честі та гідності, справедливе і шанобливе ставлення з боку керівників, колег та інших осіб; право на участь у професійних спілках з метою захисту своїх прав та інтересів; право на участь у діяльності об'єднань громадян, крім політичних партій);

2) права публічного службовця, пов'язані з належним перебігом службово-трудових обов'язків (право на чітке визначення посадових обов'язків; право на безперешкодне ознайомлення 3 документами про проходження ним служби, у тому числі висновками щодо результатів оцінювання його службової діяльності; право на професійне навчання, зокрема державним коштом тощо);

3) права публічного службовця, що мають забезпечити належний рівень соціальної безпеки держслужбовців (право на належні для роботи умови служби та їх матеріально-технічне забезпечення; право на оплату праці залежно від обійманої посади, результатів службової діяльності, стажу служби, рангу та умов контракту про проходження служби; право на відпустки, соціальне та пенсійне забезпечення відповідно до закону тощо).

\section{Список використаних джерел:}

1. Любимов О.К. Щодо поняття та класифікації функцій державної служби. Науковий вісник публічного та приватного права. 2018. Вип. 4, Т. 2. С. 24-29.

2. Іншин М.І. Права працівників за проектом Трудового кодексу. Форум права. 2014. № 2. C. $172-175$.

3. Єрофєєнко Л.В. Трудова правосуб'єктність як елемент правового статусу працівника. Науковий вісник Міжнародного гуманітарного університету. Серія: Юриспруденція. 2015. № 15, T. 1. C. $126-128$.

4. Науково-практичний коментар до Закону України «Про державну службу» / ред. кол.: К.О. Ващенко, І.Б. Коліушко, В.П. Тимощук, В.А. Дерець (відп. ред.). Київ : ФОП Москаленко O.M., 2017. 796 c.

5. Hladky V. Some cautionary remarks on the process of desocialization of the world of work. Scientific Discoveries: Projects, Strategies and Development: Proceedings of the Internat. Scient. and Pract. Conf. (Edinburgh, Oct. 25, 2019). Edinburgh: ESP, 2019. Vol. 3. P. 38-44.

6. Панченко М.В. Правовий механізм забезпечення гідної праці державних службовців України : дис. ... д-ра юрид. наук : 12.00.05. Київ, 2019. 459 с. 